BEduManageRs Journal

Borneo Educational Management and Research Journal, Vol.2, No.1, 2021

ISSN: 2747-0504

\title{
Gabungan Kepemimpinan Kenabian (li) Dengan Kepemimpinan KI Hajar Dewantara (12) Untuk Meningkatkan Hasil Reformasi Birokrasi
}

\author{
Dwi Nugroho Hidayanto ${ }^{1}$, Abdul Rachman ${ }^{2}$ \\ Universitas Mulawarman \\ e-mail: hidayantodwinugroho@gmail.com, abdul.rachman@staff.uns.ac.id
}

\begin{abstract}
The combined of prophetic leadership and trilogy leadership concepts called as neo-prophetic leadership. The neo-prophetic leadership covers prophets characteristics and Dewantara's teachings. The combining two leaderships models -then become L1L2- is believed able to increase result of bureaucratic reformation. The combination referred to descriptive and prescriptive theories which were developed from theoretical and empirical perspectives. In this writing, LI as a symbol of Prophetic Leadership, and L2 as a symbol of Dewantara's Leadership which he is a bringer of leadership trilogy teachings. This is a leadership prescription that derived from eternal universal values-prophetic- while still maintaining local wisdom values -trilogy- which its effectiveness detail explained descriptively. L1L2 need to be tested by leaders and placed the organization as a laboratoryto try-out it.
\end{abstract}

Keywords: bureaucratic reformation, prophetic leadership, trilogy leadership, the effectiveness.

\section{PENDAHULUAN}

Ada banyak konsep kepemimpinan yang ditawarkan oleh para ahli dalam rangka meningkatkan birokrasi. Konsep-konsep sebagai pandangan dengan didasarkan pada studi teoritis dan empiris masing-masing memiliki kekuatan serta kelemahannya di dalamnya. Umumnya, studi teoritis dengan perspektif mereka sendiri memiliki kekuatan di atasnya menggambarkan konsep lebih inklusif dan universal di mana entitas pengguna untuk ini sudah tahu. Adapun kelemahannya, studi teoritis tidak selalu didukung oleh bukti empiris yang berkembang secara dinamis dan konsekuensinya bahwa teori-teoriini dikategorikan sebagai teori yang kedaluwarsa dan kedaluwarsa. Untuk studi empiris mereka memiliki kekuatan sendiri pada penjelasan berbasis data dan temuan penelitian, adapun kelemahannya adalah pembatasan besarnya generalisasinya, tidak representatif atau berkelanjutan pada masyarakat ChanGing. Idealnya, harus ada teori kepemimpinan reseptif, tidak hanya yang deskriptif. Teori kepemimpinan preskriptif ditekankan seperti rumus yang didasarkan pada hasil diagnostik untuk mengangkat kesehatan organisasi. Adapun teori deskriptif lebih menekankan pada penjelasan fenomena kepemimpinan dalam sebuah organisasi. Sejalan dengan birokrasi sebuah rea yang mencakup organisasi, tata kelola, regulasi, aparatur, pengawasan, pertanggungjawaban, pelayanan publik, dan pola budaya kerja membutuhkan resep kepemimpinan yang berkelanjutan yang mampu mengatasi dinamika perubahan zaman. Dengan kata lain, ini adalah resep kepemimpinan yang berasal dari nilai-nilai universal abadi dengan tetap mempertimbangkan kearifan lokal yang terjaga dengan baik.

Adership lekenabian diyakini memiliki nilai-nilai universal dan mampu mengatasi dimensi waktu. Yang terpercaya, dapat dipercaya, cerdas, dan keterbukaan adalah perwakilan dari sifat positif yang perlu setiap pemimpin miliki. Kepemimpinan kenabian dapat dilihat sebagai kombinasi teori deskriptif dan reseptif. Begitu juga trilogi kepemimpinan Ki Hajar Dewantara yang terdiri dari tiga prinsip, adalah: di depan menjadi role model (ing ngarsa sung tuladha), di tengah antusiasme bangunan (ing madya mangun karsa)dan motivasi tak hentihentinya (tut wuri handayani). Trilogi ini lahir dari pertimbangan pendidikan dalam rangka mengoptimalkan tujuan pendidikan 
BEduManageRs Journal

Borneo Educational Management and Research Journal, Vol.2, No.1, 2021

ISSN: 2747-0504

dengan isinya yang fleksibel dan universal yang dapat diterapkan di berbagai jenis organisasi.

Berangkat dari keterangan di atas, penulis berniat membangun konsep kepemimpinan dengan menggabungkan Model Kepemimpinan Kenabian (L1) dengan Trilogi Kepemimpinan $\mathrm{Ki}$ Hajar Dewantara Model (L2) dan efektivitas mereka untuk meningkatkan prestasi goal birokrasi. Langkah-langkah keberhasilan pelayanan sipil (birokratis) adalah: tidak ada korupsi, tidak ada pelanggaran, Anggaran Pemerintah Nasional dan Daerah berada di jalur yang benar, semua program dilakukan dengan baik, semua izin usaha selesai dengan cepat dan tepat, komunikasi publik berjalan dengan baik, efektif dan produktif penggunaan waktu, konsisten dalam pelaksanaan reward and punishment, dan hasil pembangunan nyata.

Semuaeasurement $\mathrm{m}$ di atas adalah efek yang dilakukan oleh human resources apparatus (HRA). Oleh karena itu, HRA adalah area inti yang perlu dikembangkan dengan cara-cara seperti itu untuk menghidupkan sinergi ke daerah terkait lainnya. HRA sebagai orang-orang di balik pistol reformatibirokrasi pada adalah subjek serta objek dalam kepemimpinan organisasi. L1 dan L2 dinilai sebagai model kepemimpinan yang cukup untuk menghasilkan DA maju untuk memimpin roda organisasi di Era Reformasi Birokrasi (BRE).

\section{Kepemimpinan Kenabian (L1)}

Ini adalah model kepemimpinan yang dilakukan oleh para nabi dalam membimbing pengikut mereka. Abioje (2010) menulis dalam artikelnya bahwa " beberapa ulama berbicara tentang nabi sebagai revolusioner moral ....". Sebagai pemimpin, para nabi memimpin para pengikut berdasarkan sifat melekat mereka sendiri serta prasyarat mutlak bagi semua nabi. Siddiq, adalah orang yang dipercaya; amanah, dapat dipercaya; fatonah, cerdas, dan; tabligh adalah keterbukaan dalam menyampaikan ajaran, adalah sifat universal nabi. Para nabi dalam melaksanakan kepemimpinan tidak didasarkan pada nafsu, sebagaimana Turpin (2005: 15) menekankan bahwa para pemimpin kenabian adalah orang-orang doa dan ibadah, mereka hidup untuk dekat dengan hati Allah dan mendengarkan apa yang Dia katakan. Dalam beberapa waktu terakhir, tidak ada nabi lagi, but tidak sedikit orangmewarisi karakter nabi. Tentu saja, mereka layak mendapatkan mandat kepemimpinan, termasuk kepemimpinan di BRE.

Di antara para nabi dan pemimpin, Muhammad Nabi diakui sebagai pemimpin yang paling sukses kemudian pemimpin lain. Keberhasilan itu diyakini mewakili karakternya. Seperti yang dikatakan Ratnawati (www.baktinusa.com), Muhammadnabi mampu menggabungkan dua kepemimpinan dalam satu tubuh, sebagai pemimpin agama serta pemimpin dunia. Kepemimpinan sejati teladan melekat pada Nabi Muhammad sebagai pemimpin yang holistik, diterima, dan terbukti. Dinyatakan sebagai pemimpin holistik karena kemampuannya untuk mengembangkan kepemimpinan di berbagai bidang termasuk pengembangan diri, bisnis dan kewirausahaan,

Kebenaran kekal sebagai pemimpin kenabian backrest adalah kekuatan utama dalam melaksanakan kepemimpinan. Sejarah membuktikan, bahkan pada masa-masa awal ia menghadapi penolakan dan perlawanan yang kuat dari sebagian besar masyarakat tetapi pada akhirnya pada titik tertentu lahir dari kesadaran mereka untuk " ini" yang benar dan perlu diikuti.

\section{Kekuatan Kepemimpinan (L2)}

Ada anggapan bahwa L2 lebih sebagai kearifan lokal dan bernuansa Jawa. Asumsi datang disebabkan oleh pengabakan ajaran yang kebetulan seorang tokoh Jawa dan tentunya sangat terbiasa dengan budaya Jawa. Ki Hajar Dewantara yang asal nama Suwardi Suryaningrat adalah inisiator Trilogi Kepemimpinan. Dalam L2 diperkenalkan juga Three Con (konsentrat, kontinuitas, konvergensi) untuk mendidik siswa sebagai calon pemimpin bangsa. Meskipun asal ide-ide ini berasal dari kearifan 
BEduManageRs Journal

Borneo Educational Management and Research Journal, Vol.2, No.1, 2021

ISSN: 2747-0504

lokal tetapi nilai-nilai cover universal. Siapa pun dan dalam organisasi mana pun ketika dia menjadi pemimpin harus menjadi model pribadi dengan cara yang baik (logy pertama), dan siapa pun di organisasi mana pun ketika dia seorang pemimpin harus mengembangkan inisiatif dan motivasi (logy kedua), dan siapa pun di organisasi mana pun ketika dia seorang pemimpin harus membangkitkan dorongan (l ogy ketiga).

Universalitas nilai-nilai yang tampak sangat sederhana di L2 adalah kekuatan untuk membangkitkan sinergi organisasi. Dari nilainilai ini, organisasi dapat belajar. Itu adalah pelajaran yang dipelajari untuk menjadi organisasi pembelajaran. Tidak sulit bagi para pemimpin di era modern untuk menguraikan L2 dalam rangka mengembangkan kinerja organisasi dan birokrasi. Bukan berarti mengembangkan inisiatif (BR) selalu berasal dari pemimpin tertinggi? Dari sini terlihat jelas bahwa L2 tidak kehilangan relevansi antara lain model kepemimpinan yang terus berkembang.

\section{Kekuatan Kombinasi (L1L2)}

Menggabungkan atau mensintesis L1 dengan L2 menjadi L1L2 itu tidak berarti bahwa tidak adanya satu akan melemahkan yang lain. L1 memiliki kekuatan tersendiri sehingga L2 masih memiliki keunggulan tersendiri. Namun, dalam context Indonesia, angkat hanya $\mathrm{K} 1$ yang akan membawa dengan konsekuensi pada penganggaran sektarian dan fundamentalisme. Sebaliknya, jika kita memiliki cukup dengan L2 oleh karena itu membawa dengan konsekuensi yang diasumsikan sebagai fanatik sektoral serta etnosentrisme. Oleh karena itu, L1L2 gabungan dapat ditempatkan sebagai konsep netral sambil mempertahankan kekuatan satu sama lain. Combine L1L2 yang memadukan antara karakter nabi dengan trilogi kepemimpinan akan mempermudah pemimpin dalam melaksanakan kepemimpinan dalam rangka BR. L1 lebih menekankan dalam dimensi "apa" sementara L2 lebih menekankan dalam dimensi "metode". Siapa pun (pemimpin dan juga yang dipimpin) dan dalam organisasi apa pun, ketika di posisi depan serta di tengah atau di belakang masih membutuhkan karakter nabi yang bersifat universal. L1L2 adalah inspirasi dalam menjalankan kepemimpinan yang sempurna dalam rangka mendapatkan BR. L1L2 adalah inspirasi untuk BR.

\section{Luas dan Hasil BR}

Ada delapan bidang BR dan sembilan standar keberhasilan produk BR. Bidang BR terdiri dari: organisasi, tata kelola, regulasi, aparatur sumber daya manusia, pengendalian, pertanggungjawaban, pelayanan publik, dan budaya kerja. Adapun standar keberhasilan BR these adalah: tidak ada korupsi, tidak ada pelanggaran, anggaran yang baik di tingkat nasional maupun regional, semua program yang dicapai dengan baik, menggunakan waktu secara efektif secara efisien serta produktif, lisensi bisnis dikeluarkan dalam waktu yang tepat, komunikasi publik yang dilakukan dengan baik, konsistensi dalam implementasi reward and punishment, dan hasil pengembangan nyata. Diharapkan, oleh BR semua organisasi akan hak ukuran dan fungsi yang tepat, sistem serta prosedur dan proses kerja yang lebih jelas, efektif, efisien dan dapat diukur sebagai prinsip-prinsip tata kelola yang baik, memiliki peraturan yang baik dan kondusif dan tidak tumpang tindih, lahir manusia sumber daya dengan integritas yang baik, netral, kompeten, profesional, kinerja tinggi dan sejahtera, meningkatkan tata kelola pemerintahan yang bersih dan baik serta bebas dari korupsi-kolusinepotisme, peningkatan kapasitas dan kinerja birokrasi yang akuntategta, pelayanan prima seperti yang diharapkan masyarakat, pola berpikir formasi dan budaya kerja dengan integritas dan kinerja yang lebih tinggi.

Berdasarkan sembilan standar keberhasilan BR oleh karena itu langkah nyata mudah diwujudkan karena pengukuran yang jelas. L1L2 akan sangat membantu 1 untukmewujudkan BR karenasejalan dengan budaya Indonesia dan pemikiran paradigma mereka yang fidelity, benar untuk janji dan ditaati kepada pemimpin, oleh karena itu diperlukan figur yang dicontohkan untuk menentukan program yang sukses. Sebagus 
BEduManageRs Journal

Borneo Educational Management and Research Journal, Vol.2, No.1, 2021

ISSN: 2747-0504

apapun konsep BR, tidak akan efektif jika tidak didukung oleh kepemimpinan yang baik. L1K2 adalah kualitas kepemimpinan yang baik, dan secara ilmiah dan alami akan membantu pelaksanaan BR di semua tingkat birokrasi.

\section{Efektivitas L1L2 untuk Meningkatkan Pencapaian Hasil BR}

Sebagai perwakilan dari kepemimpinan karakter universal, L1L2 diyakini sebagai model yang sangat efektif untuk meningkatkan hasil BR. Seperti dijelaskan di atas, L1L2 sangat efektif untuk mendukung hasil BR. Jika efektivitas berkasi pada hasil (kualitas dantivitas produksi) L1L2 yang diyakini mampu memanfaatkan kualitas kinerja dan produktivitas aparatur birokrasi di semua tingkat organisasi. Mengubah karakter kenabian dalam bingkai trilogi kepemimpinan kemudian penekanan pada pemberdayaan pemimpin sumber daya manusia dan yang dipimpin lebih jelas, dan oleh pemimpin panutan, sinergi total akan terjadi di semua organisasi tingkatan. Organisasi akan lebih dinamis, tata kelola akan lebih terbuka serta lebih terorganisir, peraturan hukum akan more dipahami dan diinternalisasi, aparatur birokrasi akan bekerja optimal sesuai tugas mereka, pengendalian akan tumbuh dalam bentuk pengendalian diri (tumbuh dari hati), lebih tinggi pertanggungjawabannya, pelayanan publik meningkat, dan pola $\mathrm{e}$ culturkerja akan lebih baik karena mind set lift ke tingkat yang lebih tinggi karena organisasi pembelajaran tumbuh secara bersamaan.

Jika sinergi total telah terjadi berdasarkan karakter kenabian dalam bingkai trilogi kepemimpinan, oleh karena itu di bangsa ini tidak akan terjadi korupsi, tidak ada pelanggaran, penganggaran pemerintah nasional dan daerah akan lebih baik dalam menyerap dan tidak ada kebocoran, semua program tercapai, lisensi bisnis yang dikeluarkan tepat waktu, komunikasi publik dilakukan dengan baik, efisien dan produktif dalam menggunakan waktu, reward dan punishment melaksanakan secara konsisten, dan hasil pembangunan nyata. Keberhasilan yang diyakini menjadi kenyataan karena mereka yang dipimpin dan mereka yang memimpin telah menumbuhkan kesadaran dari hati mereka dan mencoba untuk menempatkan masing-masing dari mereka selalu dalam cara-cara jalan (shiddiq), dapat dipercaya dan tidak pernah berbohong (amanah) ini menjaga mandat dengan baik, terbuka dan akuntabel yang berarti menyampaikanapa yang perlu dikatakan(tabligh), dan menjadi bagian dari organisasi pembelajaran untuk tetap cerdas (fathonah).

\section{KESIMPULAN}

Sebagai ide-ide lama yang diperbarui (kemudian disebut sebagai kepemimpinan neokenabian) akan tampak aneh pada pikiran orang-orang yang tidak ingin membuka diri. Penolakan dari berbagai pihak terhadap konsep L1L2 menjadi tantangan yang harus dihadapi. Oleh karena itu, sosialisasi yang dinilai dari atas ke bawah patut dilakukan. Para pemimpin perlu memahami terlebih dahulu konsep L1L2, kemudian membawanya untuk hidup dan mempraktikkannya. Melalui pemahaman dan praktik secara berkelanjutan akan mendorong lahirnya mekanisme yang melekat dalam membangun karakter anggota organisasi dan perasaan bersalah selalu muncul jika tidak berbuat baik. Akhirnya, implementasi L1L2 akan memimpin peningkatan kemampuan massif, itu berarti bahwa semua kompetensi anggota organisasi (c) dan karakter (ch) akan berkembang, di mana c + ch adalahelemen pembentukan kemampuany. Sebagai teori reseptif, L1L2 perlu diuji oleh para pemimpin dan menempatkan organisasi sebagai laboratorium untuk pembentukan karakter. Kesediaan menguji efektivitas L1L merupakan salah satu bukti komitmen para pemimpin untuk mewujudkan BR. Melalui implementasi L1L2, BR menjadi lebih nyata. Jadi, coba saja.

\section{DAFTAR PUSTAKA}

Abioje, P.O. 2010. Critical prophecy and political leadership in biblical, African and Islamic worldviews. www.scielo. org. za > koers .

Anonim, 2012. Pedoman Perumusan Kebijakan (Edits Revisi). Jakarta: Pusat Kajian Manajemen Kebijakan, Deputi II Bidang 
BEduManageRs Journal

Borneo Educational Management and Research Journal, Vol.2, No.1, 2021

ISSN: 2747-0504

Kajian Manajemen Kebijakan dan Pelayanan Lembaga Administrasi Negara.

Firdaus, Bachtiar, 2016. Prophetic Leadership. Jakarta : Pustaka Saga.

Muhammad, NMN. 2015. "Prophetic Leadership Model: Conceptualizing a Prophet's Leadership Behaviour, Leader Follower Mutuality and Altruism to Decisions Making Quality”. European Journal of Interdisciplinary Studies. www. juornals.euser. org $>$ article> view.

Mustopadijaya, 2013. Reformasi Birokrasi sebagai Syarat Pemberantasan KKN. Makalah disampaikan pada Seminar Pembangunan Nasional VIII diselenggarakan oleh Badan Pembinaan Hukum Nasional Departemen Kehakiman dan Hak Asasi Manusia. Denpasar: Kemenkum \& HAM.

NurulFaridah, 2013. Konsep Kepemimpinan Ki Hajar Dewantara.(www. blogspot.com.2013/05/)

Turpin JR., J. Randolph A., 2005. A Model for Prophetic Leaders. Cleveland, Tennessee, Churchof God Theological Seminary.

www.baktinusa.com/54/prophetic leadershipmenggali kepemimpinan sang nabirahim-menempa negarawan muda sejati. 